\title{
Miasta przyszłości. W poszukiwaniu nowego paradygmatu zarzadzania i rozwoju, Alfred Lutrzykowski, Robert Musiałkiewicz i Fabian Nalikowski (red.), Państwowa Wyższa Szkoła Zawodowa we Włocławku, Włocławek 2017, ISBN 978-83-60607-78-7, ss. 210
}

Cities of the future. In search of a new management and development paradigm, Alfred Lutrzykowski, Robert Musiałkiewicz i Fabian Nalikowski (Eds.), Państwowa Wyższa Szkoła Zawodowa we Włocławku, Włocławek 2017, ISBN 978-83-60607-78-7, 210 pages

\section{Streszczenie:}

Miasta są istotnym element funkcjonowania państwa i w sposób zasadniczy determinują jego potencjał. Celem niniejszego artykułu recenzyjnego jest przedstawienie jak kwestię zarzadzania i rozwoju aglomeracji miejskich, w aspekcie teoretycznych i praktycznym, analizują autorzy artykułów zawartych w książce pt. „Miasta przyszłości. W poszukiwaniu nowego paradygmatu zarzadzania i rozwoju”. Jej redaktorzy, Alfred Lutrzykowski, Robert Musiałkiewicz i Fabian Nalikowski, podjęli się wraz $\mathrm{z}$ autorami tekstów określenia nowych wyznaczników $\mathrm{w}$ rozwoju struktur miejskich.

Słowa kluczowe: miasto, zarządzanie miastem, rewitalizacja, rozwój miasta

Abstract:

Cities are an important element of the functioning of the state and fundamentally determine its potential. The purpose of this review is to present how the issue of management and development of urban agglomerations, in theoretical and practical 
Katarzyna Maciejewska-Mieszkowska - „Miasta przyszłości...” [rec.]

aspects, is analyzed by the authors of the articles contained in the book 'Cities of the future. In search of a new management and development paradigm'. Its editors Alfred Lutrzykowski, Robert Musiałkiewicz and Fabian Nalikowski - undertook with the authors of the texts to define new determinants in the development of urban structures.

Keywords: city, city management, revitalization, city development

W jednej z reklam telewizyjnych mówi się o mieście tak: „Miasto ściąga mnie i odpycha. Raz pasuje jak garnitur na miarę. Raz drażni jak kamień w bucie. (...) Uciekam od miasta, a potem wracam, by się nim od nowa nasycić. (...) Miasto gęste, brudne, wstrętne, piękne. Piękne w swej niedoskonałości"1. Współczesne polskie miasta mają niewątpliwie prawo wzbudzać tak skrajne odczucia i rzeczywiście są niedoskonałe, niemniej jednak nie zmienia to faktu, iż są ośrodkami, które stanowią jeden z zasadniczych elementów struktury administracyjnej państwa. Szczególnie dotyczy to miast wojewódzkich oraz tych, które utraciły ten status w wyniku reformy w 1999 r. Ich postrzeganie i ocena zarówno przez mieszkańców, jak i osoby tylko chwilowo je odwiedzające uwarunkowana jest wieloma czynnikami, np.: społeczno-demograficznymi, politycznymi, gospodarczo-ekonomicznymi, technologicznymi czy historycznymi. Jaka jest jednak przyszłość miast? Czym uwarunkowany jest ich rozwój? A także za pomocą jakich instrumentów będzie on kształtowany? To pytania, na które nie ma jednoznacznych odpowiedzi, bo tak jak różne są miasta tak różne są koncepcje ich przyszłości.

Wieloautorska monografia pod redakcją Alfreda Lutrzykowskiego, Roberta Musiałkiewicza i Fabiana Nalikowskiego pt. „Miasta przyszłości. W poszukiwaniu nowego paradygmatu zarządzania i rozwoju" stara się zapełnić tę lukę i reprezentuje teoretyczno-praktyczne podejście do kwestii rozwoju i transformacji miast w szerokiej perspektywie badawczej. Ukazała się ona jako pokłosie konferencji pod tym samym tytułem zorganizowanej w ramach uroczystości związanych

\footnotetext{
1 https://www.wirtualnemedia.pl/artykul/szczepan-twardoch-reklama-mobilnyportfel-w-raiffeisen-polbank-wideo [dostęp: 10-10-2018].
} 
z piętnastą rocznicą powstania Państwowej Wyższej Szkoły Zawodowej we Włocławku. Na książkę składa się czternaście opracowań, a ich przewodnim wątkiem jest funkcjonowanie miasta w szeroko aspektowym ujęciu.

Pierwszy z artykułów, noszący taki sam tytuł jak cała monografia, jest autorstwa Alfreda Lutrzykowskiego, współredaktora książki. Nakreślone zostało $\mathrm{w}$ nim szerokie spectrum podejść badawczych do zjawiska jakim jest miasto. Według autora miasto jest niezwykle dynamiczną i stale przekształcającą się tkanką społeczną, której rozwój determinowany jest nie tylko czynnikami pragmatycznymi czy industrialnymi istotnymi w kontekście funkcjonowania państwa, ale również czynnikami psychologicznymi. Człowiek jako mieszkaniec miasta będzie zatem musiał zmierzyć się z nowymi wyzwaniami związanymi z metropolitarnym charakterem miejsca, w którym żyje.

Drugi tekst, którego autorem jest Hubert Izdebski, nosi tytuł „Zarządzanie miastem - tradycje i wyzwania przyszłości", a jego zasadniczy element stanowi przedstawienie zależności w rozumieniu pojęć „miasto” oraz „zarządzanie miastem” przez obywateli. Podobnie jak we wcześniejszym artykule ujęcie problemu jest wieloaspektowe ze szczególnym uwzględnieniem mieszkańców miast jako członków danej społeczności oraz osób współzarządzających stale ewoluującą strukturą miejską.

Tomasz Kaczmarek w opracowaniu „Koncepcja governance w zarządzaniu terytorialnym. Wybrane aspekty" analizuje jej założenia ze szczególnym uwzględnieniem wykorzystania ich na poziomie lokalnym samorządu terytorialnego. Istotne $\mathrm{w}$ tym względzie są uwagi dotyczące występujących w zarządzaniu polskimi miastami niedoskonałości, ze szczególnym uwzględnieniem deficytu uczestnictwa społecznego w tej materii. Szans zmiany na lepsze w tej kwestii autor szuka w integracji europejskiej oraz nowym programie spójnościowym Unii Europejskiej - Zintegrowane Inwestycje Terytorialne.

Rozdział napisany przez Grzegorza Rydlewskiego „Miasto jako wyzwanie i szansa dla decydowania publicznego. Zarys problemów 
Katarzyna Maciejewska-Mieszkowska - „Miasta przyszłości...” [rec.]

wg przyjętego wzoru" ukazuje miasta jako jeden z istotnych elementów decydujących o rozwoju poszczególnych państw i regionów. Autor określa je nawet mianem "lokomotyw rozwoju i agentem zmiany”, a ich miejsce i znaczenie $\mathrm{w}$ polityce polskich władz analizuje w kontekście przyjętej przez rząd w 2017 roku Strategii na rzecz Odpowiedzialnego Rozwoju do roku 2020 oraz materiałów opublikowanych w 2011 roku przez Komisję Europejską. Zaznacza on też, iż wspólnym zadaniem praktyków i teoretyków zajmujących się problematyką miast jest znalezienie nowego modelu ich zarządzania i rozwoju.

Kolejny tekst zawarty w prezentowanej książce, autorstwa Andrzeja Potoczka „Przestrzenny kontekst współczesnego rozwoju lokalnego i regionalnego" mówi o praktycznym i zasadniczym czynniku rozwoju jednostek terytorialnych, jakim jest położenie w konkretnej przestrzeni z uwzględnieniem uwarunkowań społecznych i gospodarczych. Uwzględnienie charakterystyki i cech danego obszaru jest bowiem niezbędne w celu efektywnego zarządzania daną jednostką, ale również wypracowania nowych zasad współpracy samorządów w zakresie realizacji wspólnych celów i inwestycji. Obszarem, w ramach którego takie działania mogą być realizowane, są Zintegrowane Inwestycje Terytorialne.

Robert Musiałkiewicz w artykule „Koncepcja Smart City - kiedy miasto staje się inteligentne?" pochyla się nad możliwościami wprowadzenia w życie idei Inteligentnych Miast. Mają one być odpowiedzią na bolączki w zakresie m.in. takich dziedzin jak transport i mobilność, technologie budowlane oraz zarządzanie energią, a także szeroko rozumiane inteligentne zarządzanie mające na celu zwiększenie partycypacji mieszkańców w działaniach publicznych. Ich wprowadzenie wymaga stworzenia i połączenia ze sobą kapitału ludzkiego i społecznego oraz infrastruktury informacyjnej i komunikacyjnej, co przełoży się na rozwój miast i polepszy jakość życia mieszkańców.

W rozdziale pt. „Bezpieczeństwo jako wyzwanie miast przyszłości” Robert Gawłowski porusza niezwykle ważny temat dotyczący zmian sposobu zarządzania bezpieczeństwem w mieście w ujęciu koncepcji community policing. Wskazuje on, jak istotne dla wzmocnienia poczu- 
cia bezpieczeństwa jednostki było nawiązanie bezpośrednich kontaktów i współpracy policji z mieszkańcami oraz określenie na tej podstawie problemów ważnych z punktu widzenia obywateli. Kolejnym krokiem jest włączenie ich $w$ działania bezpośrednie. Niestety na poziomie polskich struktur miejskich koncepcja ta zdaniem autora nadal pozostaje w sferze teorii.

Inny aspekt zarządzania miastem w tekście „Ekonomia doznań a kształtowanie przestrzeni miejskiej" uwzględnia Edyta PłaskonkaPruszak. Autorka wyjaśnia, na czym polega i w czym przejawia się ekonomia doznań w funkcjonowaniu miasta, a także jak jej zastosowanie może wpływać pozytywnie na jakość życia mieszkańców, co w konsekwencji przełoży się na postrzeganie miasta jako miejsca atrakcyjnego w wielu aspektach życia, w tym kultury, odpoczynku czy rozrywki. Jednym z wymiernych efektów jej zastosowania w kształtowaniu przestrzeni miejskiej jest zapobieganie przenoszeniu się mieszkańców miast na tereny podmiejskie.

Marcin Pelc w artykule „Rewitalizacja - regulacja ustawowa i meandry praktyki" dzieli się swymi spostrzeżeniami dotyczącymi trudności związanych z rewitalizacją przestrzeni miejskich, ze szczególnym uwzględnieniem rozbieżności w zakresie rozwiązań prawnych, a faktycznym ich zastosowaniem przez władze samorządowe. Działaniem, które mogłoby zapobiec rozbieżnościom i nadużyciom w tym zakresie, jest zdaniem autora dokonanie zmian w przepisach przejściowych, przy jednoczesnej standaryzacji procedur przygotowywania i ustalania programów rewitalizacji.

Kolejne opracowanie, którego autorką jest Janina Kowalik, nosi tytuł „Od rewitalizacji do kryzysu przestrzeni centralnej miasta. Przypadek Kielc”. Jest ono studium przypadku i wskazuje przyczyny i skutki tylko częściowo udanej rewitalizacji Śródmieścia Kielc. Z ustaleń autorki wynika, iż efekty pozytywne w tym zakresie można odnotować tylko w kwestiach: wizualnych, infrastrukturalnych i technicznych. Nie nastąpiły natomiast oczekiwane zmiany ekonomiczne i społeczne będące zasadniczym wyznacznikiem powodzenia rewitalizacji miasta. 
Katarzyna Maciejewska-Mieszkowska - „Miasta przyszłości...” [rec.]

Przyczyn takiego stanu rzeczy upatruje ona w braku spójności decyzji władz miejskich.

Problematyce rewitalizacji poświęcony jest również tekst Fabiana Nalikowskiego pt. „Gminny program rewitalizacji - instrument przywracający funkcjonalność obszarom zdegradowanym”. Wskazuje on istotne różnice między gminnymi a lokalnymi programami rewitalizacji, a także uwzględnia aspekt prawny i proceduralny wdrażania go w życie. Zdaniem autora gminny program rewitalizacji jest szczególnie istotny dla miast średniej wielkości, które utraciły status miast wojewódzkich.

Sebastian Kozłowski w rozdziale pt. „Dylematy organizacyjne samorządu warszawskiego w świetle wyzwań metropolitarnych" podjął się określenia najważniejszych kwestii w rozwoju i funkcjonowaniu polskiej stolicy. Zagadnienie niezwykle rozległe i wielowątkowe przedstawił w sposób syntetyczny, z uwzględnieniem takich aspektów jak: bieżąca polityka krajowa, potencjał i status Warszawy oraz reformy organizacyjne w aspekcie transformacji systemowej państwa. Konkluzja z przedstawionych rozważań wskazuje, iż dotychczasowe działania podjęte na rzecz zmiany ustroju miasta tylko w niewielkim stopniu miały za zadanie poprawić funkcjonowanie miasta i zaspokoić oczekiwania jego mieszkańców.

Jedyny obcojęzyczny artykuł w monografii nosi tytuł „The role of universities in local sustainable development". Jego autorzy, Ruslan Demchyshak i Zoriana Zazuliak, przedstawiają interesującą analizę roli uniwersytetów w lokalnym zrównoważonym rozwoju, w ramach której to teorii uwzględniane są czynniki ekonomiczne, społeczne i środowiskowe. Rozważania teoretyczne odnoszone są do sytuacji na Ukrainie i jej potencjału naukowego.

Całość monografii zamyka materiał prezydenta Włocławka Marka Wojtkowskiego, którego tytuł brzmi „Problem rewitalizacji Włocławka - niemożność czy realna perspektywa?”. Powyższe zagadnienie zostało ujęte z perspektywy praktyka, który w celu zobrazowania złożoności zadania, jakim jest rewitalizacja, przedstawia wyciąg ustaleń ze „Szczegółowej diagnozy obszaru rewitalizacji Włocławka”. 
Artykuły zawarte w prezentowanej książce podejmują zagadnienie zarządzania miastem w szerokiej perspektywie badawczej i uzupełniają się wzajemnie. Przedstawione przez autorów konkluzje dotyczące zmian w zarządzaniu i rozwoju miast przyszłości mają charakter zarówno teoretyczny, jak i praktyczny. W książce przeważa jednak warstwa deskrypcyjna przed eksplikacyjną, co powoduje, że przedstawione przez autorów postulaty i wnioski dotyczące zmian w zarządzaniu i rozwoju miast przyszłości są mniej przekonujące. Publikacja koncentruje się, przede wszystkim, na charakterystyce rozwoju polskich miast, co z jednej strony pozwala na określenie ich specyfiki, $\mathrm{z}$ drugiej stosunkowo marginalnie potraktowano aspekt potencjału ich rozwoju na tle środowisk miejskich innych państw. Istotne wzmocnienie monografii stanowiłoby także poszerzenie odwołań w zakresie literatury dotyczącej poruszanej problematyki. Niewątpliwie pozytywną i szczególnie istotną cechą książki jest to, iż teksty w niej zawarte traktują strukturę aglomeracji miejskich jako żywą, dynamiczną i stale ewoluującą tkankę, którą można i należy wzmacniać oraz rekonstruować, by działała sprawniej i efektywniej jako konstytutywny element konstrukcji państwa. Kondycja miast i ich mieszkańców przekłada się bowiem na jakość regionów, a w konsekwencji na potencjał kraju. Publikację należy potraktować nie tylko jako teoretyczne rozważania nad jakością i możliwościami rozwoju miast, ale również, a może przede wszystkim, jako drogowskaz dla włodarzy i praktyków działających na rzecz struktur miejskich. Powinna ona także zachęcić przedstawicieli środowisk naukowych do kontynuowania i poszerzenia badań w zakresie tej interesującej społecznie problematyki. 